\title{
Chemistry and technology of roasting and extracting different types of coffees with preservation of taste and aromas
}

\author{
Sergiy Kurta, Maria Yakubiak, Olga Khatsevych \\ Department of Chemistry, Faculty of Natural Sciences, Vasyl Stefanyk Precarpathian National \\ University, Ivano-Frankivsk, Ukraine.
}

\section{kca2014@ukr.net}

Keywords: green, black, coffee beans, aromatic, taste, components, microwave, DTA, MAC, analysis, alcohol, metabolism.

The article considers the chemistry and technology of the methods of roasting and extracting different types of coffees, Arabica and Robusta. Parameters and equipment to improve roasting in microwave ovens and distillation of coffee with water-alcohol vapors demonstrate that the weight loss of green coffee beans has decreased from $18-20 \%$ to $12-15 \%$. Mass spectroscopic analysis of extracts of coffee substances with water vapor and alcohol identified 36 substances, 14 of them being the main substances that create a unique bouquet - the taste and aroma of coffee. We have experimentally demonstrated that aqueous distillates of coffee extracts accelerate 1.5-2.5 times the metabolism of ethyl alcohol in the human body to the acceptable concentrations of $0.2 \%$ per ppm.

\section{Introduction}

Coffee is the most popular product in the world after oil. Natural and instant coffee is in greater demand than gas, gold, corn or sugar. The world drinks 500 billion cups of coffee every year [1]. Coffee is a unique mixture of flavors and aromas that begin to appear at the time of roasting, grinding and extraction of these components, when brewing coffee in water. Therefore, the study of biochemical and organoleptic aromatic and taste properties of coffee in extracts and distillates with water and alcohol is an urgent problem.

The aim of the work is to find alternative methods of roasting with microwave, grinding coffee beans and extracting aqueous-alcoholic solutions and coffee distillates, analyzing their DTA, MAC, IR spectroscopy and molecular weight distribution of the obtained substances, studying their effect on speed metabolism of alcohol in the human body with a breathalyzer.

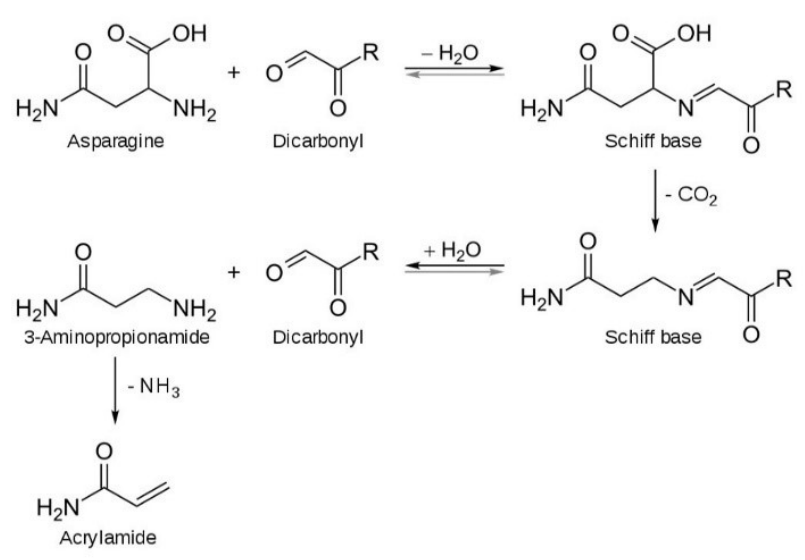

Figure 1. Reaction №1 this is one of the initial stages of the Maillard reaction: the conversion of asparagine into acrylamide. 
Figure 1 shows the Maillard reaction during heat treatment of green coffee roasting, which includes several stages: 1) the reactive carbonyl group of the sugar interacts with the nucleophilic group of the amino acid to form glycosylamine and water, 2) glycosylamine is rearranged by Amadori and converted to ketosamine, 3) ketosamines can be converted into reductones, and other diacetyl products, aspirin, pyruvaldehyde, acrylamide or colored nitrogencontaining polymers and melanoidins [2]. The Maillard reaction leads to the formation of numerous products, sometimes with a rather complex and yet unknown structure. This reaction occurs for example while roasting meat or baking bread, as well as roasting coffee. In the process of heating the food, there is a typical smell, color and taste of cooked food, including coffee. At the same time, organic products derived from pyridine should appear in coffee [3].

\section{Experimental part}

\section{Material and methods}

Our studies were performed using the method of DTA (differential thermal analysis) on a derivatograph Q-1000D MOM (Paulik-Erdey). To do this, coffee samples (92.4 and $99.9 \mathrm{mg}$, respectively) were heated at a programmed rate $\left(5^{\circ}\right.$ and $10^{\circ} \mathrm{C} / \mathrm{min}$ ) to a given temperature (125 ${ }^{\circ}$ and $250^{\circ} \mathrm{C}$, respectively). After switching off the heating, data recording (TG, DTG, DTA and $\mathrm{T}$ in the sample) was continued for an average of another $0.5 \mathrm{~h}$ until the output of the DTA curve gives constant values. TG, DTG, DTA and T in the sample are given (Figure 4) as a function of time. The TG curve was converted to $\%$.

Our research allowed obtaining optimal technological conditions for the isothermal roasting of green coffee beans of Arabica "Brasil Santos" and Robusta "Vietnam" in the microwave isothermal reactor MWR-SPR ("Microwave reactor for Solid-phase reactions Milestone, Italy"(Figure 2).

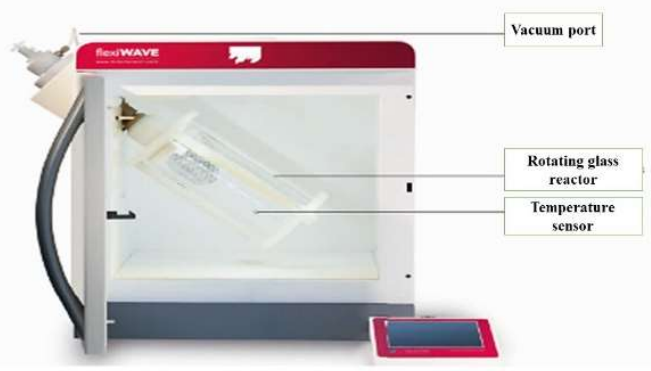

Figure 2. Microwave laboratory rotary reactor for solidphase reactions, incl. for thermo-vacuum roasting of green coffee with the automatic controller of temperature and time.

The reactor was equipped with a rotary or glass reactor with a magnetic stirrer: $\mathrm{n}=150-250 \mathrm{rpm}$. The roasting time was 15-20 minutes (Table 2), and the weight loss of coffee beans after roasting was $\Delta \mathrm{M}=15-18 \%$ at $20-195^{\circ} \mathrm{C}$. The power of the microwave oven reached $\mathrm{N}=300-800 \mathrm{~W}$, which is significantly different from the conditions of traditional coffee roasting on fire or with an electric heating, where roasting takes place at temperatures of $220-260{ }^{\circ} \mathrm{C}$ [4].

We created a laboratory installation using a microwave oven (Figure 3) and improved the method of distillation of fragrant and aromatic 
substances of ground coffee with water vapor and ethyl alcohol of different concentrations.

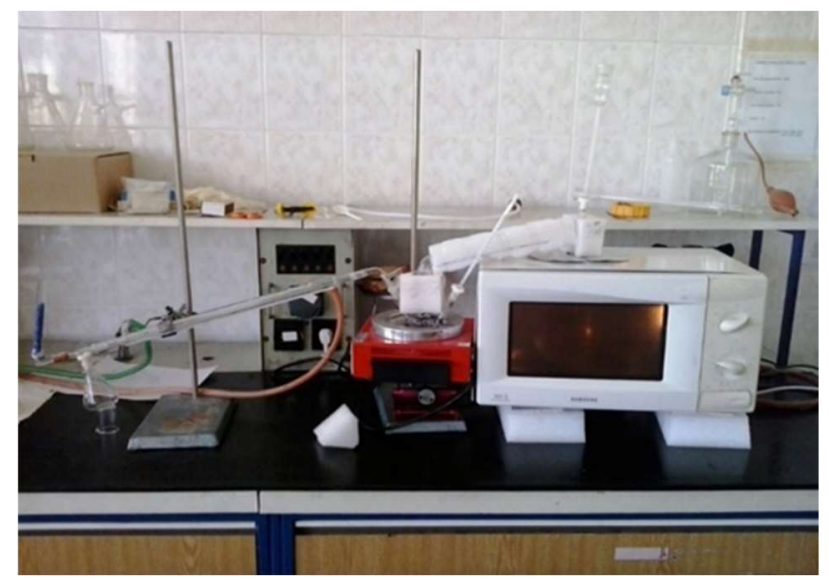

Figure 3. Laboratory equipement for extraction of aromas of natural black coffee with water-alcohol vapors using a microwave oven.

To determine the qualitative and quantitative composition and molecular weight of components extracted from distillates of coffees differents varieties in water and ethanol, we used a MAC spectrometer (MALDI-ToF and LDIToF), matrix-activated laser desorption / ionization and laser desorption (Autoflex II LRF 20 BrukerDaltonics) device $\mathrm{nm}$ with a pulse time of 3 ns. Samples coffee in solution or samples in the matrix were applied to a standard steel target and dried. Both methods are equipped with a time analyzer and were implemented under standard conditions. Each mass spectrum obtained during the study is isolated from the sum of 200 individual mass spectra. The analyzer was used in linear mode. The studies were performed in the range of 100-6000 Da. Matrices for MALDI-ToF studies were used in a 1: 1 ration with the sample. A $1 \mu l$ aliquot of trifluoroacetic acid was added to the solutions. [6]. Molecular weight and size distribution of coffee nanoparticles was made with a preliminary analysis of the separation of particles by laser light angular distribution (NANODS CILAS).

Using the Alcofor-105 breathalyzer, we performed a preliminary analysis of the exhaled air samples before and after consumption of coffee samples and coffee extracts and distillates.

\section{Results and discussion}

As we can see on the obtained DTA curves, (see Table 1, Figure 4) numerous aromatic substances, whose composition and structure are described below, are formed and released when roasting coffee.
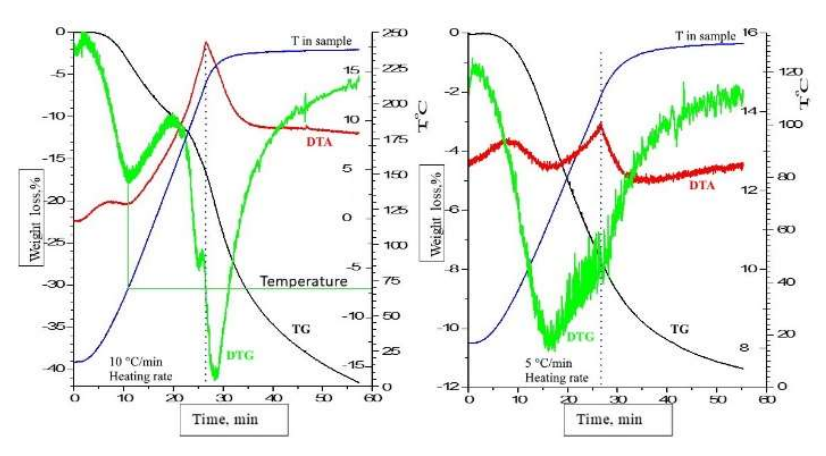

Figure 4. DTA curves of Arabica green coffee:

1) Heating rate $\mathrm{V}=10 \mathrm{degrees} / \min$ to $250^{\circ} \mathrm{C}$

2) Heating rate $\mathrm{V}=5$ degrees $/ \min$ to $130^{\circ} \mathrm{C}$ 
Table 1. DTA analysis of curves of Arabica green coffee during its heat treatment (roasting)

\begin{tabular}{|c|c|c|c|c|c|c|c|c|c|c|c|c|c|c|c|c|}
\hline \multirow{2}{*}{ № } & \multirow{2}{*}{ 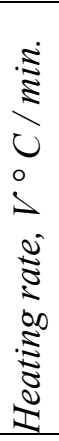 } & \multirow{2}{*}{ 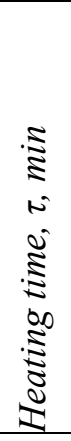 } & \multirow{2}{*}{ 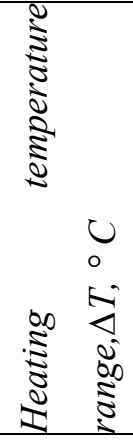 } & \multirow{2}{*}{\multicolumn{2}{|c|}{ 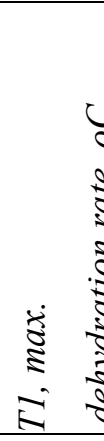 }} & \multirow{2}{*}{\multicolumn{2}{|c|}{ 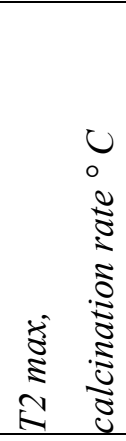 }} & \multirow{2}{*}{ 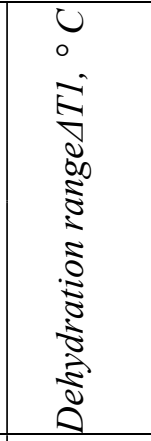 } & \multirow[b]{2}{*}{ 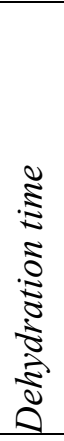 } & \multirow{2}{*}{ 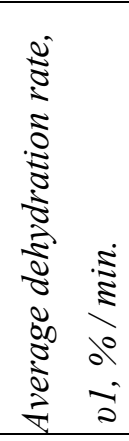 } & \multicolumn{3}{|c|}{$\begin{array}{l}\text { Weight loss } \\
\text { coffee, } \\
\Delta m 2, \%\end{array}$} & \multirow{2}{*}{ 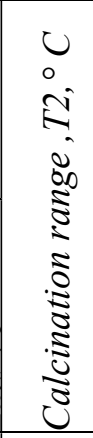 } & \multirow{2}{*}{ 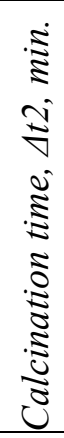 } & \multirow{2}{*}{ 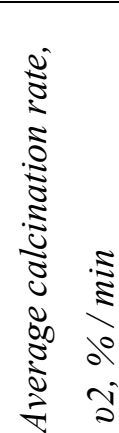 } \\
\hline & & & & & & & & & & & 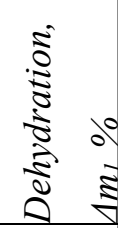 & 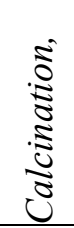 & & & & \\
\hline 1 & 10 & 28 & $20-240$ & 70 & & 230 & & $20-150$ & 16 & 0.625 & 10 & 32 & & $\begin{array}{l}150- \\
230\end{array}$ & 36 & 0.88 \\
\hline 2 & 5 & 28 & $18-130$ & 66 & & 115 & & $18-130$ & 28 & 0.22 & 11,5 & - & & - & - & - \\
\hline
\end{tabular}

Caramelization of coffee, during its roasting, is a stage of formation of condensed (colored) compounds. The formed substances have a system of conjugated bonds that adsorb light with certain wavelengths, giving the products a brown color. At $190-200{ }^{\circ} \mathrm{C}$, unsaturated condensed polymers are formed. Some of the products formed are: caramelan $-\mathrm{C}_{12} \mathrm{H}_{18} \mathrm{O}_{9}$, caramelen$\mathrm{C}_{24} \mathrm{H}_{36} \mathrm{O}_{18}$, caramelin- $\mathrm{C}_{36} \mathrm{H}_{50} \mathrm{O}_{15}$ and small amounts of humic $\left(\mathrm{C}_{125} \mathrm{H}_{188} \mathrm{O}_{80}\right)$. Caramelan, caramelen and caramelin are brown powders, and give a bitter taste to the coffee. Polymeric humic compounds $\left(\mathrm{C}_{125} \mathrm{H}_{188} \mathrm{O}_{80}\right)$ have a dark brown color and a bitter taste. Caramel derivatives (possible formula $\mathrm{C}_{36} \mathrm{H}_{50} \mathrm{O}_{15}$ ) have a different color intensity, melting point, solubility in water / alcohol, and angle of light rotation depending on the degree of dehydration:
1- caramelan: $\operatorname{tml}=145^{\circ} \mathrm{C},[\alpha] 20 \mathrm{D}=80^{\circ}$, easily soluble $\mathrm{H}_{2} \mathrm{O}$ and $80 \% \mathrm{CH}_{3} \mathrm{OH}$ solution;

2- caramelen: $\operatorname{tml}=205{ }^{\circ} \mathrm{C},[\alpha] 20 \mathrm{D}=64.5^{\circ}$, soluble in $\mathrm{H}_{2} \mathrm{O}$;

3-caramelin: does not melt, $[\alpha] 20 \mathrm{D}=$-, dissolves in $\mathrm{H}_{2} \mathrm{O}$ when boiling [5].

When roasting coffee, the formation of each new unsaturated bond $(-\mathrm{C}=\mathrm{C}-)$ leads to a deepening and darkening of color of the caramelized coffee, according to the reaction №2.(Figure 5). The IR spectra of coffee extracts obtained on the FTIR spectrometer Nicolet i S50; ThermoScien'fic, evidenced the presence of caffeine in the region of $1600 \mathrm{~cm}-1$ and other aromatic substances of acidic nature in the region of $1400 \mathrm{~cm}-1$, ketone or aldehyde groups in the region of $1200 \mathrm{~cm}-1$ (Figure 6). 
Table 2. Conditions of roasting green Arabic coffee on a microwave isothermal chamber MWR-SPR: "Microwave reactor for Solid-phase reactions, Milestone, Italy", at the Faculty of Industrial Technology, Trenchin University named after Ya. Dubchak, Pukhov. Slovak People's Republic.

\begin{tabular}{|c|c|c|c|c|c|c|c|c|}
\hline \multirow[t]{2}{*}{ № } & \multirow[t]{2}{*}{$\begin{array}{l}\text { Degree of coffee } \\
\quad \text { roasting }\end{array}$} & \multirow[t]{2}{*}{ Coffee Properties } & 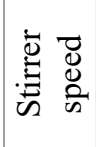 & 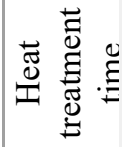 & $\begin{array}{ll}\frac{1}{5} & 0 \\
\frac{000}{0} & 0 \\
0 & 0 \\
3 & 0\end{array}$ & 竞 & $\begin{array}{l}\dot{0} \\
\sum_{0}^{0} z\end{array}$ & \multirow[t]{2}{*}{ Characteristics } \\
\hline & & & $\mathrm{r} / \mathrm{min}$ & min. & $\%$ & ${ }^{\circ} \mathrm{C}$ & $W t$ & \\
\hline & $\begin{array}{l}\text { Green coffee, } \\
\text { varieties Arabica, } \\
\text { kind "Brasil Santos" } \\
\text { firm «Salvia } \\
\text { Paradise» in the } \\
\text { Czech Republic }\end{array}$ & $\begin{array}{l}\text { 1.Drying stage: Raw beans, } \\
\text { green coffee (pale green } \\
\text { almost odorless) Drying of } \\
\text { coffee from humidity (at } 60^{\circ} \\
\text { C for } 15 \text { minutes) at the } \\
\text { drying container for drying in } \\
\text { the open the air. }\end{array}$ & 250 & 15 & $0,5-2,5$ & $20-60$ & 300 & $\begin{array}{l}\text { Green (green with a gray } \\
\text { tinge) unpleasant odor and } \\
\text { smooth grains. Some coffee } \\
\text { beans near the magnetic the } \\
\text { stirrers turned yellow and even } \\
\text { darkened to a dark yellow } \\
\text { color. The flask became } \\
\text { cloudy from evaporated water. }\end{array}$ \\
\hline 2 & $\begin{array}{l}\text { Brown } \\
\text { coffee, varieties } \\
\text { Arabica, kind } \\
\text { "Brasil Santos" firm } \\
\text { «Salvia Paradise» } \\
\text { packaged in the } \\
\text { Czech Republic }\end{array}$ & $\begin{array}{l}\text { 2. After the drying stage №1 } \\
\text { (at } 60^{\circ} \mathrm{C}, 15 \text { min. } \Delta \mathrm{m}=1,9 \\
\% \text { ). Burning using a reflux } \\
\text { condenser and a water reflux } \\
\text { condenser: evaporation of } \\
\text { water leads to the expansion } \\
\text { of the grain. }\end{array}$ & 250 & $+20=35$ & 2,8 & $35-105^{\circ}$ & 300 & $\begin{array}{l}\text { There is evenly from yellow to } \\
\text { light brown. The smell of the } \\
\text { green coffee disappeared. } \\
\text { There is a slight saturation of } \\
\text { taste, weak aroma with a bread } \\
\text { smell. } \\
\text { Loss of the upper shell (scales) } \\
\text { from the surface of the coffee }\end{array}$ \\
\hline 3 & $\begin{array}{c}\text { Brown } \\
\text { coffee, varieties } \\
\text { Arabica, kind } \\
\text { "Brasil Santos" firm } \\
\text { «Salvia Paradise», }\end{array}$ & $\begin{array}{l}\text { 2.After the drying stage is } \\
\text { roasting using a reflux } \\
\text { condenser. } \\
\text { There is increased microwave } \\
\text { reactor power. }\end{array}$ & 250 & $+20=35$ & 4,8 & $35-125^{\circ}$ & 400 & $\begin{array}{l}\text { There is a moderately dark } \\
\text { brown color, with a dry } \\
\text { surface. The smell of roasted } \\
\text { coffee appeared. Loss of the } \\
\text { upper shell (scales) from the } \\
\text { surface of the coffee. }\end{array}$ \\
\hline 4 & $\begin{array}{l}\text { Brown, } \\
\text { coffee, varieties } \\
\text { Arabica, kind } \\
\text { "Brasil Santos" } \\
\text { firma «Salvia }\end{array}$ & $\begin{array}{l}\text { 4. After the drying stage, } \\
\text { roasting is carried out in } \\
\text { isothermal mode using a } \\
\text { reflux condenser in a conical } \\
\text { flask with a magnetic stirrer. } \\
\text { There is increased power. }\end{array}$ & 250 & $+20=40$ & 3,5 & $20-135$ & 600 & $\begin{array}{l}\text { Brown coffee with a specific } \\
\text { smell of well-roasted coffee } \\
\text { (partial smell of baked bread). } \\
\text { The differences between the } \\
\text { grains are preserved. They } \\
\text { increase in size by } 1.5 \text { times, } \\
\text { and traces of coffee oil. } \\
\end{array}$ \\
\hline 5 & $\begin{array}{c}\text { Americano } \\
\text { coffee, varieties } \\
\text { Arabica, kind } \\
\text { "Brasil Santos" } \\
\text { firma «Salvia } \\
\text { Paradise», Brasilia, }\end{array}$ & $\begin{array}{l}\text { 5. After the drying stage, } \\
\text { roasting is carried out using a } \\
\text { reflux condenser in a conical } \\
\text { flask with a magnetic stirrer. } \\
\text { There is increased microwave } \\
\text { reactor power. }\end{array}$ & 250 & 20 & 13,5 & $20-145$ & 700 & $\begin{array}{l}\text { Dark brown coffee with a } \\
\text { specific smell of well-roasted } \\
\text { coffee. They increase in size } \\
\text { by } 1.5 \text { times, and traces of } \\
\text { coffee oil appear in some } \\
\text { places. The husk is completely } \\
\text { removed from the surface of } \\
\text { coffee beans. }\end{array}$ \\
\hline & & $\begin{array}{l}\text { 5.1. After the drying step, } \\
\text { annealing is carried out } \\
\text { continu-ously using a reflux } \\
\text { condenser with a } 250 \mathrm{ml} \\
\text { conical flask and a magnetic } \\
\text { stirrer.Theoretical losses = } \\
15,0 \% \text {. }\end{array}$ & 250 & 20 & 13,5 & $20-145$ & 800 & $\begin{array}{l}\text { Black roasted coffee. Grains } \\
\text { burst "twice crak" from the } \\
\text { release of gases. There is a } \\
\text { brown color of medium } \\
\text { saturation. They increase in } \\
\text { size by } 2 \text { times, traces of oil } \\
\text { appear on the surface of coffee } \\
\text { beans. The stage of "sintering" } \\
\text { and partial charring ends. }\end{array}$ \\
\hline 6. & $\begin{array}{l}\text { Americano coffee, } \\
\text { Arabica }\end{array}$ & Total & 250 & $\Sigma=40$ & $15-16 \%$ & $20-145$ & $\begin{array}{c}300- \\
800\end{array}$ & $\begin{array}{l}\text { Black roasted coffee with a } \\
\text { pleasant coffee smell and } \\
\text { taste }\end{array}$ \\
\hline
\end{tabular}




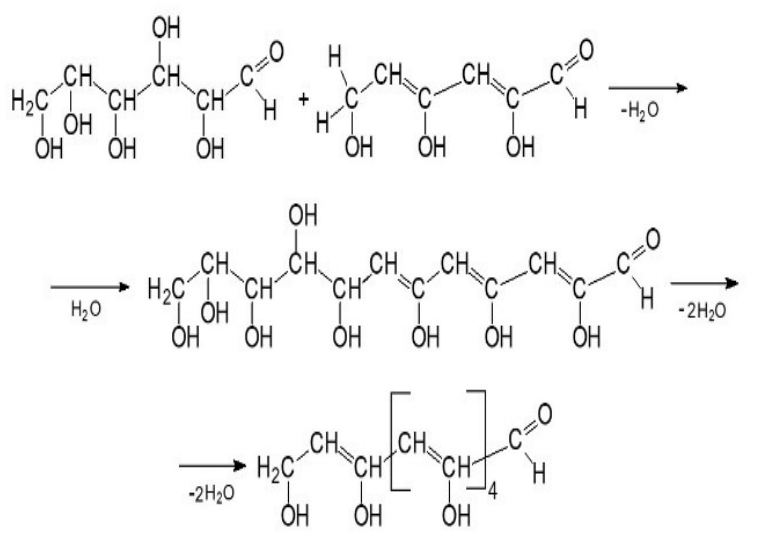

Figure 5. Reaction №2 of caramel formation from sugars during roasting.

But to decipher this complex mixture, a quantitative analysis of MAC spectra was used to determine the molecular weights of substances detected by MALDI-ToF.

Each mass spectrum obtained during the study was separated from the sum of 200 individual mass spectra of this complex coffee mixture. Then we performed the quantitative analysis of the mass spectra of coffee extracts, according to the molecular weights of substances obtained from mass spectrometry [6].

Analyzes of three samples of coffee were performed. According to MAC spectroscopy: sample 1 in Figure 7 shows the molecular weight distribution of substances extracted from brewed black Arabica coffee in water at $90^{\circ} \mathrm{C}$; sample 2 in Figure 8. shows the molecular mass distribution of substances extracted from black Arabica coffee with water vapor at $100^{\circ} \mathrm{C}$; sample 3 in Figure 9 shows molecular mass distribution of substances extracted from Arabica black coffee with ethyl alcohol vapor at $82^{\circ} \mathrm{C}$. For the obtained aqueous-alcoholic extracts of coffee, it was found that the value of the hydrogen index of alcoholic extracts approaches neutral values of $\mathrm{pH}=4-6$, which distinguishes them from acidic aqueous extracts of coffee $\mathrm{pH}=3-4$, regardless of the type of coffee. The optical density, or light transmission, of the studied coffee extracts with ethyl alcohol decreases in comparison with water.

This indicates a more efficient extraction of aromatic and oily substances from coffee with ethyl alcohol, which is confirmed by a 2-3 times increase in the dry matter residue from alcoholic extracts of coffee [7]. Based on the molecular weights from the MAC spectrograms, histograms of the molecular weight distribution of 25 known and 10 more unidentified substances were calculated and constructed, and are presented in Figures 7.1, 8.1, 9.1 and a comparison of these 3 analyzes was made on the MMP histogram (Figure 10).
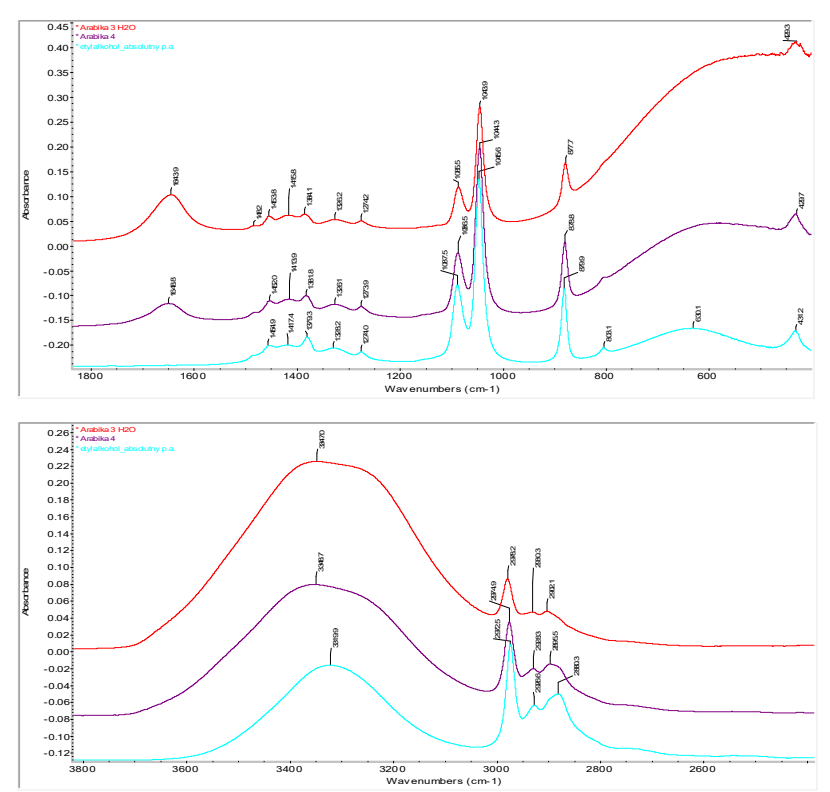

Figure 6. Comparison of IR spectra for aqueous extract of coffee-1, alcohol extract of coffee-2, and pure ethanol-3. 


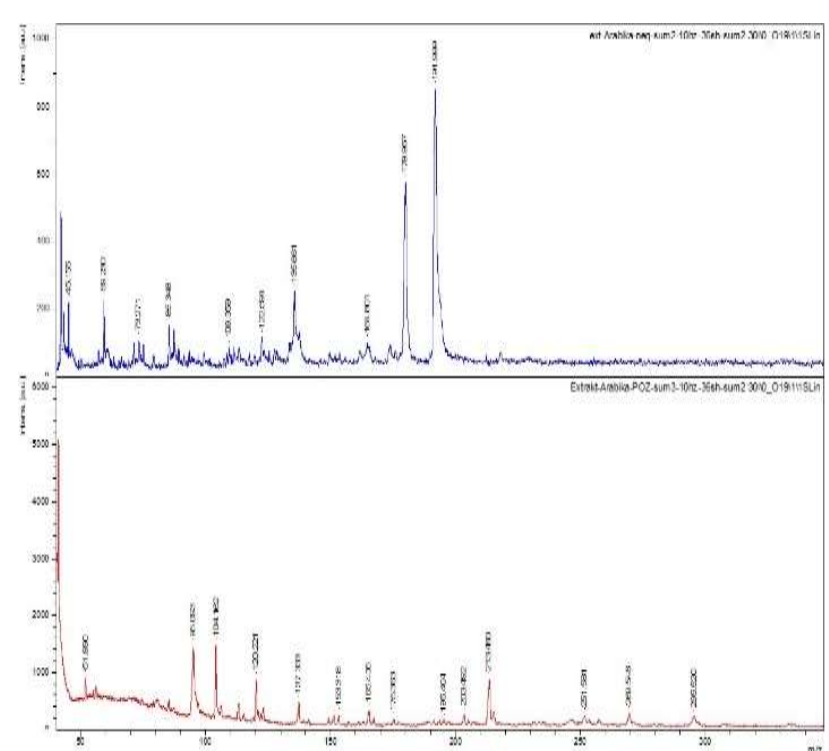

Figure 7. Mass spectra of coffee extract in water.

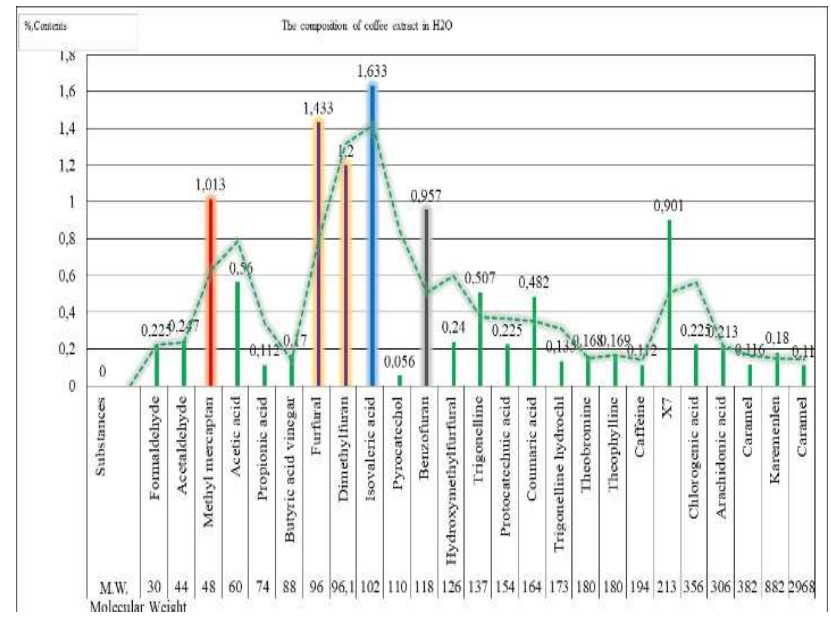

Figure 7.1. Molecular weight distribution of the substances extracted from Arabica coffee in water at $95^{\circ} \mathrm{C}$, after roasting in a microwave reactor "Milestone", according to MAC spectroscopy.

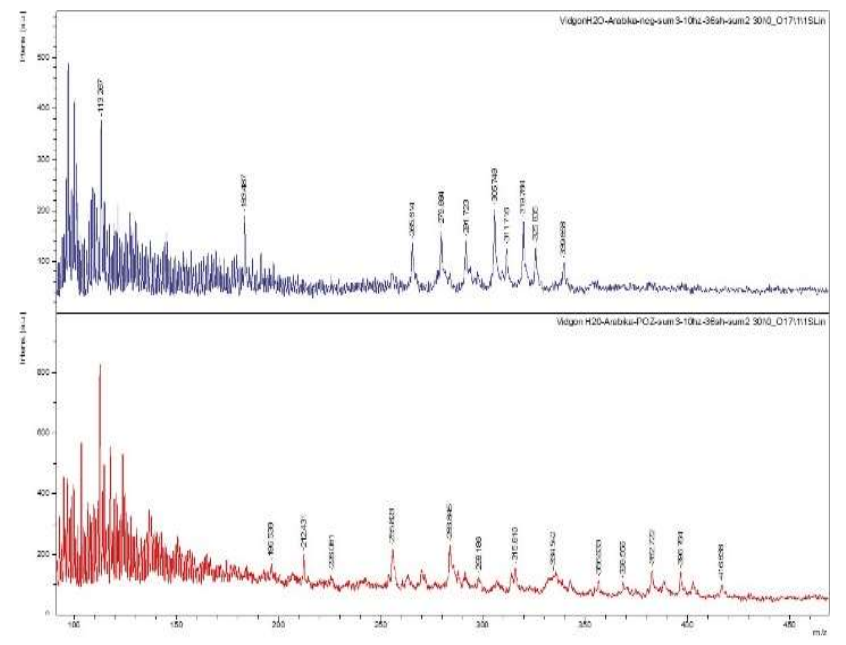

Figure 8. Mass spectra of coffee in $\mathrm{H}_{2} \mathrm{O}$ steam distillation.

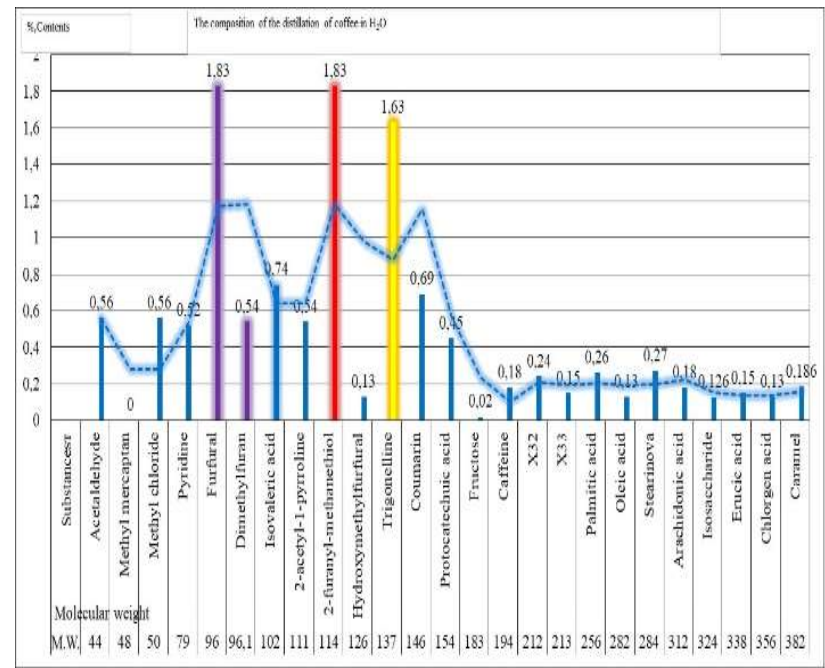

Figure 8.1. Molecular mass distribution of substances obtained by distillation with water vapor at $98{ }^{\circ} \mathrm{C}$ of Arabica coffee, after roasting in a microwave reactor "Milestone", according to MAC spectroscopy.

After analyzing the literature data [8-10] on the composition of coffee before and after roasting, taking into account our observations (see Table 3), we can summarize that the compositions differ from each other in chemical structure.

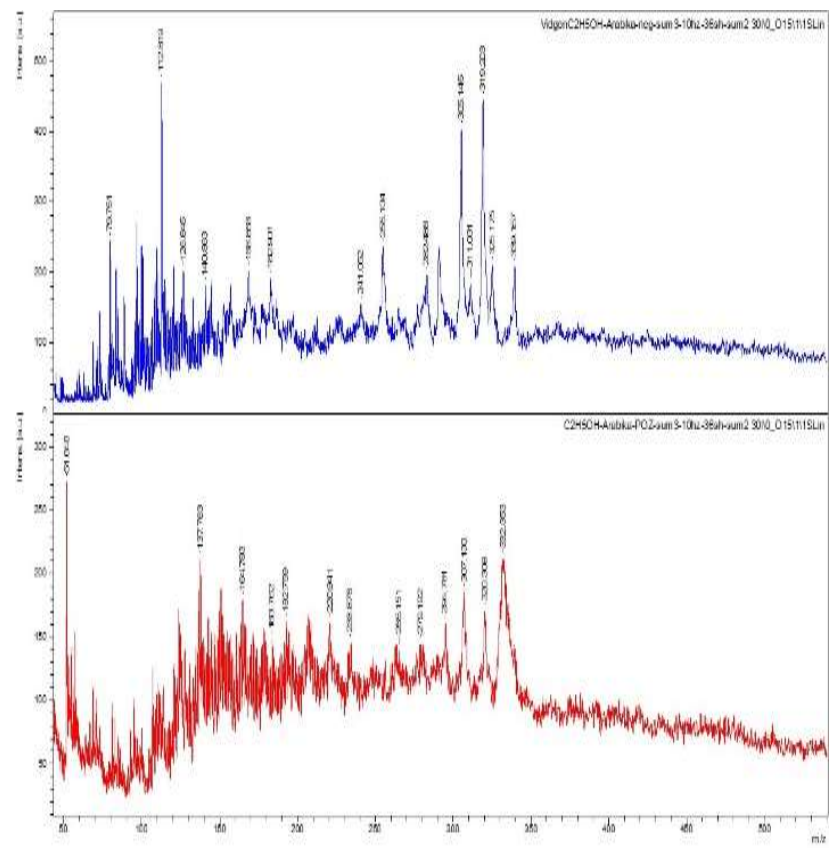

Figure 9. Mass spectra of coffee distillation with ethyl alcohol vapors. 


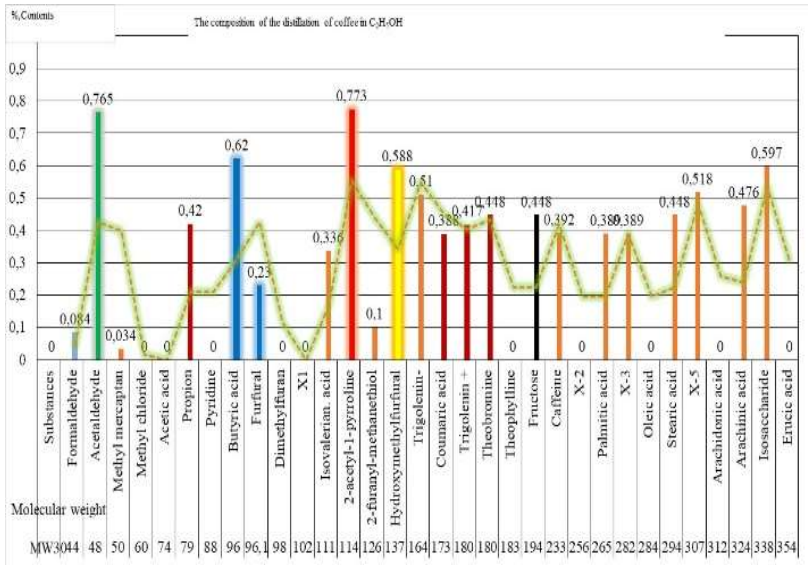

Figure 9.1. Molecular mass distribution of substances extracted from Arabica coffee by distillation with $\mathrm{C}_{2} \mathrm{H}_{5} \mathrm{OH}$ vapors at $78-82^{\circ} \mathrm{C}$, after roasting in the Milestone microwave reactor, according to MAC spectroscopy.

Therefore, we made an attempt to do this by analyzing the mass spectra of three samples of Arabica coffee, after roasting in a special microwave reactor (see Figure 3), $98^{\circ} \mathrm{C}$, after microwave roasting (Figure 4); 3) alcohol distillation of black under the conditions shown in Table 3: 1) extract of natural black Arabica coffee in water at 95 o $\mathrm{C}$, after microwave roasting (Figure 4); 2) water-steam distillation of black Arabica coffee from water atArabica coffee from $96 \%$ ethyl alcohol at $78-82^{\circ} \mathrm{C}$, after microwave roasting. Previously, based on the identification of molecular weights by mass spectroscopy, we identified 36 substances from coffee beans roasted by the microwave method. These substances come from extraction and distillation in aqueous-alcoholic solutions of coffee beans, and are presented in an aroma map [13].

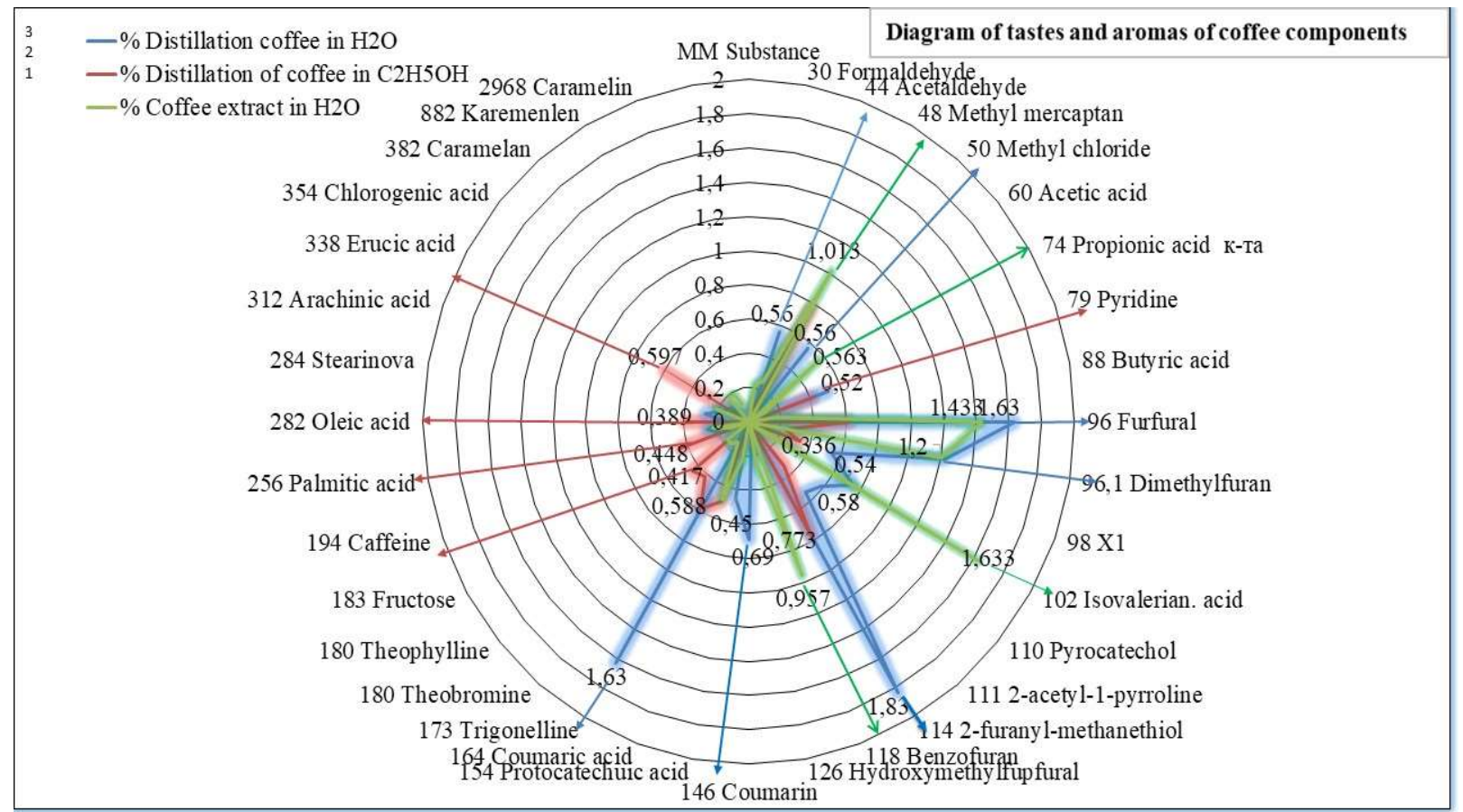

Figure 10. Comparative diagrams of tastes and aromas of Arabica coffee, according to MM distribution of substances from: 1- coffee extract in water; 2- distillation of coffee in $\mathrm{C}_{2} \mathrm{H}_{5} \mathrm{OH}$, 3- distillation of coffee in $\mathrm{H}_{2} \mathrm{O}$, after roasting in a microwave reactor "Milestone", according to MAC spectroscopy from Figures 7.8.9. 
In contrast to the 36 main and 62 additional aromatic and taste characteristics of Le Nez du Café [14] known in the literature, which represent complex aromas and tastes and which are determined only by specially prepared tasters [13], we have determined molecular weight and qualitative-quantitative composition of coffee extracts and distillates in water and ethanol containing 36 individual substances (Figure 10,

Table 3) [11].

Table 3. №1-13.[11].Comparison of the chemical composition of raw and roasted coffee $(\mathrm{g} / 100 \mathrm{~g})$ and our results №14.

\begin{tabular}{|c|c|c|c|}
\hline Substance & \multicolumn{2}{|c|}{ In raw coffee beans } & $\begin{array}{c}\text { In roasted } \\
\text { coffee }\end{array}$ \\
\hline 1. Caffeine & \multicolumn{2}{|c|}{$0,7-2,5$} & $0,63-2,25$ \\
\hline 2. Chlorogenic acid & \multicolumn{2}{|c|}{$5,5-10,9$} & $2,2-4,0$ \\
\hline 3. Tannins & \multicolumn{2}{|c|}{$3,6-7,7$} & $0,5-1,0$ \\
\hline 4. Saccharose & \multicolumn{2}{|c|}{$6,0-10,0$} & 0,56 \\
\hline 5. Reducing sugars & \multicolumn{2}{|c|}{$0,7-1,0$} & 2,22 \\
\hline 6. Minerals & \multicolumn{2}{|c|}{$3,6-4,5$} & $5,0-7,0$ \\
\hline 7. Lipids & \multicolumn{2}{|c|}{$9,4-18,0$} & $9,4-18,0$ \\
\hline 8. Protein substances & \multicolumn{2}{|c|}{$9,0-10,2$} & $7,65-9,75$ \\
\hline 9. Malic acid & \multicolumn{2}{|c|}{0,3} & 0,18 \\
\hline 10. Oxalic acid & \multicolumn{2}{|c|}{0,05} & 0,042 \\
\hline 11.Tartaric acid & \multicolumn{2}{|c|}{0,4} & 0,28 \\
\hline 12.Citric acid & \multicolumn{2}{|c|}{0,3} & 0,13 \\
\hline 13.Extract substances & \multicolumn{2}{|c|}{$20,0-29,0$} & $21,0-25,0$ \\
\hline \multirow[t]{2}{*}{$\begin{array}{l}\text { 14.Sum of experi- } \\
\text { mentally extracted } \\
\text { substances from } \\
\text { coffee in our work } \\
\text { (Kurta) [6] }\end{array}$} & $\begin{array}{l}\text { Extract } \\
\text { of cof- } \\
\text { fee in } \\
\text { water at } \\
95^{\circ} \mathrm{C}\end{array}$ & $\begin{array}{c}\text { Coffee } \\
\text { distilled } \\
\text { with } \\
\text { water } \\
\text { vapor at } \\
98^{\circ} \mathrm{C}\end{array}$ & $\begin{array}{c}\text { Coffee } \\
\text { distilled } \\
\text { with } \\
\mathrm{C}_{2} \mathrm{H}_{5} \mathrm{OH} \\
\text { vapors at } \\
78-82^{\circ}\end{array}$ \\
\hline & $11,28 \%$ & $10,053 \%$ & $7,135 \%$ \\
\hline
\end{tabular}

Thus, taking into account the data of the authors [14], and our data, we can say that the full (total) aroma and taste of coffee, its bouquet, consists of the following 13 basic substances (Figure 10 and Table 3):

1. -methylmercaptan with a pungent odorMM48,

2. -acetic acid -MM60:

3. -furfural with the smell of rye bread - MM96,

4. -dimethylfuran with caramelized aroma and taste - MM96,2;

5. -isovalerian to-and with the smell of valerian MM102;

6. -furaninmethanethiol with the smell of roasted coffee MM114,

7. -benzofuran with a sharp aromatic odor MM118,

8. -trigolenin which after roasting in coffee is converted into pyridine-MM173,

9. -coumarin-floral and herbal scent-MM146,

10.-coumar to-that with a vegetable smell and taste-MM164,

11.-caffeine is the main alkaloid of bitterness in coffee-MM194

12 -palmitic and -oleic acids have an oily odor of coffee oil -MM256-282,

13.-erucic acid with a bitter and astringent tasteMM338.

In this case, as can be seen from Figure 7, according to the MAC spectrum of the extract of brewed black Arabica coffee in water at $90^{\circ} \mathrm{C}$, and according to the molecular weight distribution of histograms in Figure 7.1, and a comparative diagram of the tastes and aromas of coffee Figure 10, the composition of coffee extract in water present six main aromatic substances:

1.- methyl mercaptan with a pungent odor MM48,

2. -acetic acid with flavor acidity -MM60:

3. -furfural with the smell of rye bread- MM96, 
4. -dimethylfuran-MM96,

5. -isovalerian to-and with the smell of valerianMM102,

6. -benzofuran with a sharp aromatic odor, MM 118.

At the same time, coffee distilled from water, according to Figures 8, 8.1, 10, creates five other aromatic substances, 2 of them being present in the aqueous extract of coffee:

1. furfural with the smell of rye bread- MM96,

2. dimethylfuran with caramelized aroma and taste - MM96,2;

3. isovalerian to-and with the smell of valerianMM102,

4. furaninmethanethiol with the smell of roasted coffee-MM114,

5. trigolenin, which after roasting in coffee is converted into pyridine $\mathrm{MM}=137$.

Coffee distilled from an aqueous solution of ethyl alcohol, according to Figure 9, 9.1, 10, created seven other aromatic substances, only three of them being present in the water distillation of coffee:

1. -methylmercaptan with a pungent odor MM48,

2. -pyridine with a foul odor-MM79;

3. -furfural with the smell of rye bread- MM96,

4. -dimethylfuran with caramelized aroma and taste - MM96,2;

6. -furaninmethanethiol with the smell of roasted coffee-MM114;

7. trigolenin which after roasting in coffee turns into pyridine MM137.
Pyridine might be a product of the Maillard reaction [16].

Obviously, this is the main reason for the different aromas of coffee in water and in alcohol solution [7]. In all samples, the tastes are constantly repeated for the smell of only 2 substances, namely: dimethylfuran $(\mathrm{MM}=96.2)$ with the aroma and taste of caramel, and furaninmethanethiol $(\mathrm{MM}=114)$ with the smell of roasted coffee, so it can be stated that these substances are creating the main taste and aroma of coffee in different solvents.

The next stage of our research was to analyze the particle sizes of aromatic macromolecules and dynamic molecular weight distribution, on a special device with angular distribution of laser light (NANODS CILAS).

When analyzing the particle size of macromolecules of aromatic substances on (NANODS CILAS) in aqueous and alcoholic extracts, it was shown that their size in aqueous extracts and distillates is an order of magnitude larger $(900-9000 \mathrm{~nm})$ than in alcoholic extracts (150-1200 nm) (Figure 11).

Additionally, we investigated the effect of extracts of coffee on the metabolism of alcohol in the human body using the Alcofor-105 breathalyzer. 
Mass distribution of black coffee nanoparticles from distillates in $\mathrm{H} 20$ and $\mathrm{C} 2 \mathrm{H} 5 \mathrm{OH}$

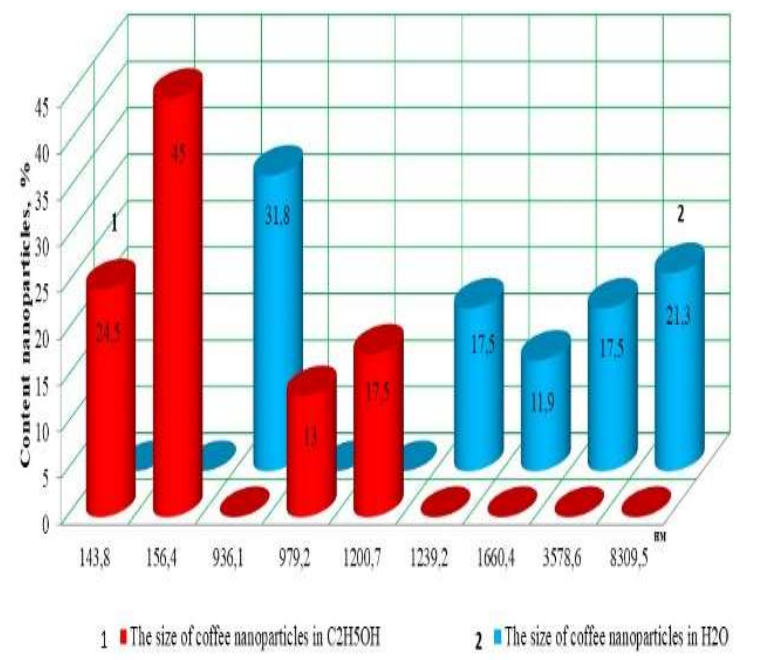

Figure 11. Nanoparticles size distribution from black coffee distillates in 1-ethanol and 2-water (nm).

It is known that when entering in the human body ethyl, alcohol is oxidized to acetaldehyde with $\mathrm{ADH}$-aldehyde dehydrogenase, which in turn is reduced back to the alcohol, according to the following equilibrium:

$$
\mathrm{C}_{2} \mathrm{H}_{5} \mathrm{OH}+\mathrm{NAD}^{+} \leftrightarrow \mathrm{CH}_{3} \mathrm{CHO}+\mathrm{NADH}+\mathrm{H}^{+}
$$

Therefore, by studying the kinetics of decomposition of ethanol and acetaldehyde, it is possible to determine the influence of some components of coffee on this process [8]. With the help of Alcofor-105 breathalyzer, we carried out a preliminary analysis of exhaled air samples after taking a dose of alcohol, during the metabolism of ethyl alcohol in the human body, by following the concentration of the alcohol in exhalation [15]. Figure 12 shows the negative impact of increasing the concentration and dose of ethanol on the rate and time of its metabolism in the human body. The time of alcohol metabolism increases from 15-25 minutes for minimum concentrations of pure ethanol (20-40 $\mathrm{ml}$ ) to 120 minutes or more, for maximum concentrations of alcohol $(60-100 \mathrm{ml})$. The catalytic effect of water-alcohol extracts of natural coffee accelerates the metabolism of alcohol and acetaldehyde in the human body, which is $1.5-2.5$ times faster than for ordinary solutions of alcohol in water. Thus, for 1 hour when using solutions of ethyl alcohol of different volumes with extracted substances of coffee flavors and aromas, the concentration of alcohol and acetaldehyde in exhaled air can be reduced to $0.2 \%$ per ppm - the permissible level for car drivers in Ukraine. [16]

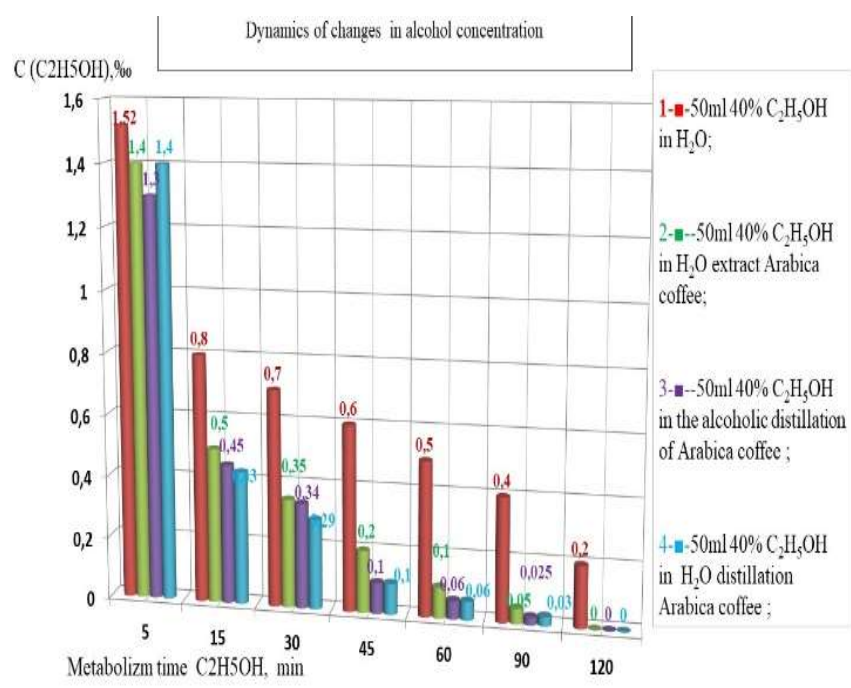

Figure 12. Histograms of the concentration of ethanol and acetaldehyde in the patient's exhaled air on the alcohol tester Alkofor-105 as a function of time and presence of coffee aromas in alcoholic beverages (test-50 $\mathrm{ml}$ of $40 \%$ ethanol).

Thus, given the above results, we can draw the following conclusions: 


\section{Conclusions}

1. New conditions for roasting green coffee beans in a microwave isothermal reactor MWRSPR were proposed and tested. They differ significantly from the conditions of traditional roasting of coffee on fire or with electrical heating at $220-260{ }^{\circ} \mathrm{C}$. During this roasting, depending on the selected type of coffee, the weight loss of coffee beans decreased from 15$20 \%$ to $12-18 \%$. The tastes and aromas of coffee are changed and the energy cost is reduced by 25 $50 \%$.

2. Analysis of data by the DTA method showed that the process of roasting coffee consists of two mutually opposite processes, endothermic dehydration of coffee at $20-130^{\circ} \mathrm{C}$, and exothermic reaction Maillard at $120-220^{\circ} \mathrm{C}$, the dehydration rate being 1.5-2 times slower than the Maillard reaction rate when roasting coffee beans.

3. The method of distillation of fragrant substances of black coffee has been improved, using the microwave oven "Disvery DY110" with water vapor and ethyl alcohol of different concentrations. It was found that the value of the hydrogen index of alcohol extracts approaches the neutral values of $\mathrm{pH}=5$, which distinguishes them from acidic aqueous extracts of coffee at $\mathrm{pH}=3$. The IR spectra of coffee extracts evidenced the presence of aromatic substances with ketone or aldehyde groups, which were identified later by MAC spectroscopy.
4. Based on the analysis of the results of MAC spectroscopy, the curves of molecular weight distribution of substances extracted in water and distilled from extracts in water and alcohol from 3 samples of coffee were constructed. 36 substances were identified, 14 of them creating the taste and aroma of coffee. It is shown that the composition of extracts-solutions of coffee in water when brewing coffee at $90^{\circ} \mathrm{C}$ includes five basic substances. At the same time for coffee distillates from an aqueous solution of ethanol, the composition of these five substances varies. Only 2 substances, namely dimethylfuran (MM96,2) with aroma and taste of caramel and furaninmethanethiol (MM114) with the smell of roasted coffee, are present in extracts and distillates of coffee in water and alcohol.

5. In the micro-analysis of the particle size of aromatic macromolecules in aqueous and alcoholic extracts on a special device with angular distribution of laser light (NANODS CILAS) it was shown that the size of coffee microparticles in aqueous extracts is an order of magnitude larger (900-9000 nm) than in extracts and distillates aqueous solution of ethyl alcohol, where they are smaller (150-1200nm). MM substances were confirmed according to MAC spectra. Substances with a higher molecular weight, even such as caramel-MM392, caramelMM882, and caramel-MM2962, are extracted and partially distilled off in water.

6. Thus, using microwaves for roasting and extracting coffee, you can get new brands of 
natural black coffee with controlled content of caffeine and other components, as well as new brands of instant coffee enriched with coffee flavors and caffeine from distillates of natural coffee in water and ethanol. Additionally, you can create food and alcoholic beverages with a natural aroma of coffee, containing substances that accelerate 1.5-2.5 times the metabolism of ethyl alcohol in the human body to acceptable concentrations of $0.2 \%$ per ppm.

\section{Supplementary information}

Figures of better quality and bigger size can be found in Supplementary files

\section{References}

[1] https://changeua.com/kavova-industriya-11-faktiv/

[2] Grandhee S, Monnier V. Mechanism of formation of the Maillard protein cross-link pentosidine. Glucose, fructose, and ascorbate as pentosidine precursors. Journal of Biological Chemistry 1991;266(18):11649-11653.

[3] Hodge J. Dehydrated Foods, Chemistry of Browning Reactions in Model Systems. Journal of Agricultural and Food Chemistry 1953;1(15):928-943.

[4] Kenneth David. Chapter Roasting Coffee: Romance and the Renaissance. Martina Griffin; November 2003; pp. 3-8, p: 256; ISBN 9780312312190.

[5] Drozdova N, Selemenev VF, Rudakov OB, Slavinskaya GV. Pigments of food productions (melanoidins). M.: DeLi print, 2008.; p: 246.

[6] Kurta SA, Buzhdygan ChV. Isolation of aromatic substances from coffee by steam distillation. Visnyk Prykarpation V. Stefanyk University. Chemistry series. 2016;20:44-51.

[7] Kurta SA, Khatsevich OM, Kurotchin MR, Buzdigan ChV. Nanostructural properties of extracts of the flavors and aromas substances natural coffee. Abstract book 7th International research and practice Conference "Nanotechnologies and Nanomaterials" NANO-2019.27-30. August 2019. Nat. Univ. "Lviv Polytechnic" str. Lviv, Ukraine. 2019. P.5.
[8] Yakubiak M, Kurta S, Khatsevich O. Nanostrukturalne właściwości ekstraktów substancji aromatycznych naturalnej kawy. Abstracty.IV Ogólnopol. Konf. Nauk. Nanotechnologia wobec oczekiwań XXI w. Lublin, 13 grudnia 2019 r. TYGIEL Poland. P.19. Available: http://bc.wydawnictwotygiel.pl/public/assets/392/IV\%20Og\%C3\%B3lnopolska\%20Ko nferencja\%20Naukowa\%20Nanotechnologia\%20wobec $\% 20$ ocz ekiwa \%C5\%84\%20XXIw.\%20Abstrakty.pdf.

[9] Burdo O, Bandura V, Zykov A, Zozulyak I, Levtrinskaya J, Marenchenko E. Development of wave technologies to intensify heat and mass transfer processes. Eastern-European Journal of Enterprise Technologies 2017;4(11 (88)):34-42.

[10] Burdo O, Bandura V, Zykov A, Zozulyak I, Levtrinskaya J, Marenchenko E. Using of the wave technologies in intensification processes of heat and mass transfer. Eureka: Physics and Engineering 2017;4:18-24.

[11] Terziev SG, Levtrynska YO. Research of hydraulic and mass transfer processes at microwave extraction of coffee. Food industry 2017;21:127-134.

[12] Trugo LG, Macrae R. The determination of carbohydrates in coffee products using high performance liquid chromatography. 10 erne colloq, su int cafe, Paris, 1983:187-192.

[13] Taste Interactive wheel based on Coffee Taster's Flavor Wheel (2016) and World Coffee Research Sensory Lexicon (first edt. 2016) from SCAA and WCR. https://notbadcoffee.com/flavor-wheel-uk

[14] 36 aromas of coffee. Le Nez du Café. https://www.lenez.com/en/kits/coffee/revelation\#none

[15] Starchevskyy V, Ribun V, Kurta S, Khatsevich O. Properties and Composition of Absolutized Ethanol and its Effect on the Gasoline Octane Number. Chemistry \& Chemical Technology 2018;12(3):346-354.

[16] Dey A, Mukherjee A. Plant-Derived Alkaloids. Discovery and Development of Neuroprotective Agents from Natural Products 2018:237-320. 